\title{
Romidepsin Regimen
}

National Cancer Institute

\section{Source}

National Cancer Institute. Romidepsin Regimen. NCI Thesaurus. Code C160811.

A regimen consisting of romidepsin that may be used in the treatment of peripheral T-

cell lymphoma (PTCL) and primary cutaneous T-cell lymphoma (PCTCL). 